\title{
Biological activity of the aqueous extract of Lychnophora pinaster Mart.
}

\author{
D. Silveira ${ }^{*}$, H. Wagner $^{2}$, E. Chiari ${ }^{3}$, J.A. Lombardi', A.C. Assunção ${ }^{5}$, A.B. de Oliveira ${ }^{6}$, \\ D.S. Raslan ${ }^{5}$
}

${ }^{1}$ Faculdade de Ciências da Saúde, Universidade de Brasília, Campus Darcy Ribeiro. Asa Norte, 70910-900, Brasilia, DF, Brasil, ${ }^{2}$ Center of Pharma-Research, Institute of Pharmacy, LM-University of Munich, Munich, $D-81377$, Germany,

${ }^{3}$ Departamento de Parasitologia, ICB, Universidade Federal de Minas Gerais, Av. Antônio Carlos, 6.627, Campus Pampulha, 31270-901, Belo Horizonte, MG, Brasil, ${ }^{4}$ Departamento de Botânica, Universidade Estadual Paulista "Júlio de Mesquita Filho", Campus de Rio Claro, Av. 24-A 1515, Bela Vista, 13506-900, Rio Claro, SP, Brasil, ${ }^{5}$ Departamento de Química, ICEx, Universidade Federal de Minas Gerais, Av. Antônio Carlos 6627, Campus Pampulha, 31270-010, Belo Horizonte, MG, Brasil,

${ }^{6}$ Departamento de Produtos Farmacêuticos, Faculdade de Farmácia, Universidade Federal de Minas Gerais, Av. Antônio Carlos, 6627, 31270-901, Belo Horizonte, MG, Brasil

\begin{abstract}
Lyophilized aqueous extract (LAE) from Lychnophora pinaster Mart (Asteraceae) aerial parts was evaluated in the search of possible biological activities. LAE exhibited trypanocidal activity $(113.62 \mu \mathrm{g} / \mathrm{mL})$, but could not inhibit 5-lipoxygenase in vitro (17\% of inhibition). LAE chemical characterization by HPLC with UV-Diode Array Detector showed the presence of caffeic acid, isochlorogenic acid, vitexin, isovitexin and quercetin, in comparison with authentic samples.
\end{abstract}

Keywords: Lychnophora pinaster, trypanocidal activity, 5-lipoxygenase assay.

\section{INTRODUCTION}

Lychnophora species (Asteraceae) grow in Brazilian Savanah (Cerrado), in the State of Minas Gerais, Bahia and Goiás (Semir, 1991) and Distrito Federal. Almost all Lychnophora species are named "arnica" and used in folk medicine as anti-inflammatory and antirheumatism remedies (Cerqueira et al., 1987; Saúde et al., 2002) as well as antimicrobial agent (Borella et al., 1998). Commercial exploitation of "arnica-da-serra" has resulted in a devastating decline of the plant population and the Brazilian Botanical Society has included this plant species in the list of Brazilian plants that are likely to become extinct (Santos et al., 2004). On the other hand, Lychnophora species have been the target of several studies about their chemical composition and/or biological activities.

The ethyl acetate extract from aerial parts of $L$. salicifolia showed trypanocidal activity against trypomastigote forms of Trypanosoma cruzi. Such activity was due to the flavonoid quercetin-7,3',4'trimethyl ether and lychnopholic acid (Jordão et al., 2004). Aerial parts ethanol extract from L. villosissima and isolated 15-deoxygoyasenzolide (Chiari et al., 1991),
L. passerina ethanol extract and isolated goyazensolide and L. trichocarpha and isolated lychnopholide and eremantholide showed in vitro trypanocidal activity against trypomastigote forms of $T$. cruzi (Oliveira et al., 1996; Chiari et al., 1996). The ethyl acetate extract from the aerial parts of L. granmongolense also exhibited trypanocidal (trypomastigote forms of $T$. cruzi) activity (Grael et al., 2000).

The dichloromethane extract from the roots $(50$ and $100 \mathrm{mg} / \mathrm{kg})$, methylcubecin $(40 \mathrm{mg} / \mathrm{kg})$, cubecin $(40 \mathrm{mg} /$ $\mathrm{kg}$ ) (Borsato et al., 2000), 3,5-di-O-[E]-caffeoylquinic acid, 4,5-di-O-[E]-caffeoylquinic acid (Santos et al., 2005), aqueous extract from leaves and stems (Cerqueira et al. 1987) of L. ericoides, presented analgesic activity in vivo. Flavonoids isolated from the ethanol extracts of the leaves and stems of $L$. affinis, demonstrated activity in cell cultures of human nasopharyngeal carcinoma (9KB) (Le Quesne et al., 1976), as well as the sesquiterpene lactones isolated from $L$. trichocarpha presented antitumor activity against several type cells (Saúde, 1994). Acetyl lychnopholic acid isolated from the ethanol extract of L. salicifolia leaves and stems (Miguel et al., 1996) and the sesquiterpenes from L. trichocarpha presented antimicrobial activity $(100 \mu \mathrm{g} / \mathrm{mL})$ (Saúde et al., 2002). 
Lychnophora pinaster Mart, commonly known as "arnica", "arnica-da-serra" or "candeia" is used in infusions, in baths, or macerated in "cachaça" (sugarcane spirit) or ethanol as anti-flogistic, anti-rheumatic, and analgesic. In previous work, a phytochemical study of the hexane and ethanol extracts from the aerial parts of $L$. pinaster led to isolation of the $E$-isomer of lychnophoric acid (named lychnophoic acid), quercetin, 15 -deoxygoyazensolide, lupeol, a mixture of $\alpha$ - and $\beta$ amyrin, friedelin and fat acid esters mixture (Oliveira et al., 1996; Silveira et al., 2005) and saturated hydrocarbons (Duarte et al., 1999). Lychnophora pinaster hexane and ethanol extracts and isolated $E$-isomer of lychnophoric acid showed in vitro trypanocidal activity against trypomastigote forms of T. cruzi (Silveira et al., 1993; Oliveira et al., 1996). In a continuing effort to known more about this species, assays were carried out to detect biological activity of the aqueous extract from aerial parts of L. pinaster.

\section{MATERIAL AND METHODS}

\section{Plant material}

Aerial parts from Lychnophora pinaster Mart. were collected at Serra da Moeda (State of Minas Gerais, Brazil), in May 1994, and identified by Professor Julio A. Lombardi. A voucher species was deposited at Herbarium of the Departamento de Botânica, Instituto de Ciências Biológicas, Universidade Federal de Minas Gerais, Belo Horizonte, Minas Gerais, Brasil (BHCB 19520). The plant material was dried at room temperature and powdered by knife mill. The aqueous extract was obtained by infusion method, using $200 \mathrm{~g}$ of powdered plant material and $2 \mathrm{~L}$ of distillated water at $70{ }^{\circ} \mathrm{C}$. After filtration, the extract was submitted to lyophilization method ( $8.2 \%$ yield).

\section{Brine shrimp lethality test (BST)}

The assay was performed basically according to simplified Meyer's method (Meyer et al., 1982). Briefly, brine shrimp Artemia salina L. encysted eggs (Maramar) were incubated in artificial seawater at $28{ }^{\circ} \mathrm{C}$. Samples were solved in $20 \mathrm{~mL}$ of artificial seawater. Serial dilutions (triplicate) were prepared in the same solution. Metanauplii (10 units) were added to each set of tubes containing samples and the cultures further incubated for $24 \mathrm{~h}$. Controls containing only artificial seawater were included on set of experiment. Lapachol was used as reference standard. $\mathrm{LC}_{50}$ (after $24 \mathrm{~h}$ ) was calculated by Probit analysis.

\section{In vitro trypanocidal activity}

The assay was performed according Chiari et al. (1996): Albino mice infected with the Y strain of T. cruzi were used to provide trypomastigotes. The lyophilized extract was suspended in dimethyl sulfoxide (DMSO) $(0.2 \mathrm{~mL})$ plus Krebs-Ringer-glucose $(1.8 \mathrm{~mL})$ and mixed with infected blood $(0.2 \mathrm{~mL})$. A parasite density of $2 \mathrm{x}$ $10^{5} / 0.1 \mathrm{~mL}$ was calculated for each flat-bottomed test tube $(4.0 \mathrm{~mL}, 56 \times 13 \mathrm{~mm})$; control tubes with DMSO and gentian violet $(0.125 \mathrm{mg} / \mathrm{mL})$ were run in parallel. After incubation at $4{ }^{\circ} \mathrm{C}$ for $24 \mathrm{~h}$ the suspensions were examined microscopically.

\section{5-Lipoxygenase assay}

5-Lipoxigenase assay was performed according to a previously described method (Kuhl et al., 1984; Duarte et al., 2000). Briefly, porcine polynuclear lymphocytes (PMNL) were isolated by dextran sedimentation and the remaining erythrocytes removed by cell lyses. The PMNL fraction was treated with eicosatetranoic acid, a lipoxygenase inhibitor, $\mathrm{Ca}^{2+}$ and $\mathrm{Ca}^{2+}$-ionophore A23187 (Boehringer Mannheim) as inductor. After addition of crude aqueous extract in $0.05 \mathrm{~mL}$ ethanol and $0.01 \mathrm{~mL}$ $9 \mu \mathrm{M}(0.1 \mu \mathrm{Ci}) 1-\left[{ }^{14} \mathrm{C}\right]$ arachidonic acid, the mixture was incubated for $5 \mathrm{~min}$ at $37{ }^{\circ} \mathrm{C}$, followed by metabolite extraction with ethyl acetate. The solvent was then evaporated and the metabolites dissolved in ethanol before HPLC separation. HPLC fractionation was carried out on a reversed-phase column coupled to a $\beta$-scintillation detector. An estimate of 5-lipoxygenase inhibition was obtained by measuring the radioactivity of the metabolite $\left[{ }^{14} \mathrm{C}\right]-5$-hydroxy-eicosatetraenoic acid produced by different amounts of extract. The uninhibited activity was determined in the presence of controls containing ethanol. The HPLC apparatus consisted of a Merck Hitachi L6200 Intelligent Pump coupled to a Merck Hitachi AS2000 auto sampler and Berthold HPLC radioactivity monitor LB $506 \mathrm{C}-1$. The analysis was carried out using a LiChroCART 4 RP-18 (5 mm) Merck column and LiChroCART 4-4 RP-18 $(5 \mu \mathrm{m})$ precolumn. The mobile phase was composed of acetonitrile and water containing $1 \%(\mathrm{v} / \mathrm{v}) 0.1 \mathrm{M}$ phosphoric acid. The stepwise gradient started with $36 \%$ acetonitrile for 12 min then $80 \%$ acetonitrile for $15 \mathrm{~min}$ at a flow rate of $1.0 \mathrm{~mL} / \mathrm{min}$ (final time run: $27 \mathrm{~min}$ ) .

\section{Chemical constituents}

\section{L. pinaster}

HPLC analysis of crude aqueous extract from

The analysis was carried out as previously described (Duarte et al., 2000).

HP1090 Chromatograph coupled to a UV-diodearray detector and HP3392A integrator, with HP79994A software HPLC Chem-Station was used. The analysis was carried out in a LiChroCART 125-4 RP-18 $(5 \mu \mathrm{m})$ Merck Column linked to LIChroCART 4-4 RP-18 $(5 \mu \mathrm{m})$ pre-column. Authentic samples used as standard, crude extract and partially purified fractions were dissolved in methanol $(1 \mathrm{mg} / \mathrm{mL})$ and filtered through a Millex-HV 0.45 
Table 1. Phenolic compounds of the aqueous extract from the aerial parts of Lychnophora pinaster by HPLC-DAD analysis

\begin{tabular}{lcc}
\hline \multicolumn{1}{r}{ Compound } & Standard RT $(\mathrm{min})$ & Sample RT (min) \\
\hline Caffeic acid & 11.32 & 11.31 \\
Vitexin + isovitexin & 16.82 & 16.81 \\
Quercetin & 19.11 & 19.09 \\
Isochlorogenic acid & 21.90 & 21.92 \\
\hline
\end{tabular}

Mobile phase: acetonitrile and $\mathrm{H}_{2} \mathrm{O}$ containing $1.0 \%(\mathrm{v} / \mathrm{v}) 0.1 \mathrm{M}$ phosphoric acid. Elution of sample and standard substances was performed by stepwise increase in acetonitrile as follows: $1 \mathrm{~min}-5 \% ; 20 \mathrm{~min}-20 \% ; 30 \mathrm{~min}-30 \% ; 40 \mathrm{~min}-80 \% ; 50 \mathrm{~min}-95 \%$ at $1 \mathrm{~mL} / \mathrm{min}$ flow rate (time run: $50 \mathrm{~min}$ ).

$\mu \mathrm{m}$ filter (Millipore) before applying to the column. The retention time and UV spectra from standard compounds, obtained at the same conditions than crude extracts and fractions, were used to compare with samples. The mobile phase was composed of acetonitrile and water contained $1 \%(\mathrm{v} / \mathrm{v}) 0.1 \mathrm{M}$ phosphoric acid. Elution of sample and standard compounds was performed by stepwise increase in acetonitrile as follows: $1 \mathrm{~min}-5 \% ; 20 \mathrm{~min}-20 \%$; 30 $\min -30 \%$; $40 \mathrm{~min}-80 \%$; $50 \mathrm{~min}-95 \%$ at $1 \mathrm{~mL} / \mathrm{min}$ flow rate (time run: $50 \mathrm{~min}$ ).

Fractionation of crude aqueous extract by sephadex LH-20 column using bi-phase technique:

The bi-phase technique sephadex LH-20 column was performed according personal communication of Dr Christina Dunstan (LM- University, Munich). Briefly, a glass column was filled with sephadex LH-20 (Pharmacia), previously in $24 \mathrm{~h}$ contact with upper phase of an ethyl acetate: isopropanol: water mixture (10:2:2). Lychnophora pinaster extract $(200 \mathrm{mg})$ was dissolved in the $5 \mathrm{~mL}$ of lower phase of the described mixture and applied to column. The elution was carried out using the lower phase and the fractionation was monitored by TLC. Eight fraction groups were obtained and analyzed by TLC and HPLC (at the same conditions described to the crude extract).

\section{RESULTS AND DISCUSSION}

A comparison of retention times and on-line UV spectra of $L$. pinaster crude aqueous extract and fractions with authentic samples, led to characterization of the phenolic compounds showed at Table 1. Only the peaks that show retention time and on-line UV spectra similar to that showed by standards were considered. The vitexine and isovitexine presented same retention time and UV spectra. By using sephadex LH-20 bi-phase separation, it was possible to obtain a fraction containing both flavonoids. Because it was not possible to isolate the vitexine from isovitexine using usual chromatograph techniques, the mixture was submitted to peracetylation reaction and usual work-up followed by silica gel column purification, afforded vitexine and isovitexine acetylated derivatives. The identity was confirmed through their NMR spectra.
Meyer and cols. (1982) classified crude extracts into toxic $\left(\mathrm{LC}_{50}<1000 \mathrm{ppm}\right)$ and non-toxic $\left(\mathrm{LC}_{50}>1000\right.$ $\mathrm{ppm}$ ), according to the levels required to attain the $\mathrm{LC}_{50}$ in the BST assay. Based on this classification, crude aqueous extract from $L$. pinaster can be considered nontoxic. BST assay present a good correlation with several others biological assays (De Rosa et al., 1994; Ojala et al., 1999). However, during our experiments with Lychnophora extracts (Duarte, 1993; Duarte, 1999), we could not find correlation between trypanocidal activity and toxicity to $A$. salina larvae, despite this correlation was suggested by literature (Zani et al., 1995). This fact may corroborate the idea that BST assay can be used only for pre-screening purpose.

Chiari et al. (1991) consider an extract or pure substance as active when remove $100 \%$ of the trypomastigote form in blood samples from animals previously infected with the parasite. Based on the Chiari classification, the crude extract showed a good activity $(113.62 \mu \mathrm{g} / \mathrm{mL}$ killed $100 \%$ of parasites). However, at this concentration the sample caused lyses of the blood cells. The lyses maybe can be explained by the presence of saponins. Even though we were not able to isolate saponins from $L$. pinaster extracts, this class of compounds was detected in the aerial parts of $L$. pinaster during a preliminary pharmacognostic assay (Duarte, 1993)

Despite aerial parts aqueous extract (infusion) is used in folk medicine to alleviate pain and inflammation caused by contusions and rheumatism, in the 5lipoxygenase assay aqueous extract $(1.0 \mathrm{mg} / \mathrm{mL})$ inhibited only $17.3 \%$ of enzyme activity. The weak inhibitory effect to 5-lipoxygenase may be due to the low lipophilicity of the constituents present in the aqueous extract (Panthong et al., 1994).

We consider the fractionation of mixtures by the sephadex LH-20 technique used here (bi-phase) can be a non-expensive and useful tool to the phytochemical work.

\section{ACKNOWLEDGEMENTS}

Financial support from CNPq, CAPES, FAPEMIG and KFA. 


\section{REFERENCES}

Borella JC, Lopes JLC, Vichnewski W, Cunha WR, Herz W 1998. Sesquiterpene lactones, triterpenes and flavones from Lychnophora ericoides and Lychnophora villosissima. Biochem Syst Ecol 26: 671-676.

Borsato MLC, Grael CFF, Souza GEP, Lopes NP 2000. Analgesic activity of the lignans from Lychnophora ericoides. Phytochemistry 55: 809-813.

Cerqueira MBS, Souza JT, Amado Jr R, Peixoto ABF 1987. Ação analgésica do extrato bruto aquoso liofilizado do caule e folhas da Lychnophora ericoides Mart. (arnica). Cienc Cult 39: 551-555.

Chiari E, Oliveira AB, Raslan DS, Mesquita AL, Tavares KG 1991. Screening in vitro of natural products against blood forms of Trypanosoma cruzi. Trans $R$ Soc Trop Med Hyg 85: 372-374.

Chiari E, Perry KSP, Saúde DA, Duarte DS, Raslan DS, Boaventura MAD, Grandi TSM, Stehmann JR, Anjos AMG, Oliveira AB 1996. In vitro screening of Asteraceae plant species against Trypanosoma cruzi. Phytother Res 10: 636-638.

De Rosa S, De Giulio A, Iodice C 1994. Biological effects of prenylated hydroquinones: structure-activity relationship studies in antimicrobial, brine-shrimp, and fish letality assays. J Nat Prod 57: 1711-1716.

Duarte DS 1993. Estudo químico-biológico de Lychnophora pinaster Mart. Belo Horizonte, 99 p. Dissertação de Mestrado - Programa de Pós-Graduação em Química, Universidade Federal de Minas Gerais.

Duarte DS 1999. Estudo químico biomonitorado de Lychnophora pinaster Mart. (Asteraceae) e de Macfadyena ungüis-cati L. A. Gentry (Bignoniaceae). Belo Horizonte, 177 p. Tese de Doutorado - Programa de Pós-Graduação em Química, Universidade Federal de Minas Gerais.

Duarte DS, Dolabela MF, Salas CE, Raslan DS, Oliveira AB, Nenninger A, Wiedemann B, Wagner H, Lombardi J, Lopes MTP 2000. Chemical characterization and biological activity of Macfadyena unguis-cati (Bignoniaceae). J Pharm Pharmacol 52: 347-352.

Duarte DS, Saúde DA, Raslan DS, Boaventura MAD, Perry KSP 1999. Hydrocarbons from Lychnophora species (Asteraceae). Acta Hort 501: 145-148.

Dunstan C 1995. Personal Communication.

Grael CFF, Vichnewski W, Souza GEP, Callegari Lopes JL, Albuquerque S, Cunha WR 2000. A study of the trypanocidal and analgesic properties from Lychnophora granmongolense (Duarte) Semir \& Leitão Filho. Phytother Res 14: 203-206.

Jordão CO, Vichnewski W, Souza GE, Albuquerque S, Callegari Lopes JL 2004. Trypanocidal activity of chemical constituents from Lychnophora salicifolia Mart. Phytother Res 18: 332-334.

Kuhl P, Shiloh R, Jha H, Murawski U, Zilhken F 1984. 6,7,4'Trihydroxyisoflavan: a potent and selective inhibitor of 5-lypoxigenase in human and porcine peripheral blood leukocytes. Prostaglandins 28: 763-804.

Le Quesne PW, Pastore MP, Raffauf RF 1976. The cytotoxic flavonoids of Lychnophora affinis. Lloydia 36: 391394.

Meyer BN, Ferrigni NR, Putnam JE, Jacobsen LB, Nichols DE, McLaughlin JL 1982. Brine shrimp: a convenient general bioassay for active plants constituents. Planta Med 45: 31-34.

Miguel OG, Lima EO, Morais VMF, Gomes STA, Delle Monache F, Bella Cruz A, Bella Cruz RC, Cechinel Filho V 1996. Antimicrobial activity of constituents isolated from Lychnophora salicifolia (Asteraceae). Phytother Res 10: 694-696.

Ojala T, Vuorela P, Kiviranta J, Vuorela H, Hiltunen R 1999. A bioassay using Artemia salina for detecting phototoxicity of plant coumarins. Planta Med 65: 715-718

Oliveira AB, Saúde DA, Perry KSP, Duarte DS, Raslan DS, Boaventura MAD, Chiari E 1996. Trypanocidal sesquiterpenes from Lychnophora species. Phytother Res 10: 292-295.

Panthong A, Kanjanapothi D, Tuntiwachwuttikul P, Pancharoen O, Reutrakul V 1994. Anti-inflammatory activity of flavonoids. Phytomedicine 1: 141-144.

Santos MD, Gobbo-Neto L, Albarella L, De Souza GE, Lopes NP 2005.Analgesic activity of di-caffeoylquinic acids from roots of Lychnophora ericoides (Arnica da serra), J Ethnopharmacol 96: 545-549.

Santos PA, Amarante MFC, Pereira MAS, Bertoni B, França SC, Pessoa C, Moraes MO, Costa-Lotufo LV, Pereira MRP, Lopes NP 2004. Production of an antiproliferative furanoheliangolide by Lychnophora ericoides cell culture. Chem Pharm Bull 52: 14331435.

Saúde DA 1994. Estudo químico e atividade tripanossomicida de Lychnophora trichocarpha Spreng. Belo Horizonte, 136 p. Dissertação de Mestrado - Programa de PósGraduação em Química, Universidade Federal de Minas Gerais.

Saúde DA, Barrero AF, Oltra JE, Justicia J, Raslan DS, Silva EA 2002. Atividade antibacteriana de furanoeliangolídeos. Rev Bras Farmacogn 12: 710.

Semir J 1991. Revisão taxonômica de Lychnophora Mart. (Vernonieae: Compositae) 2v. Campinas, 515 p. Tese de Doutorado - Programa de Pós-Graduação em Biologia Vegetal, Universidade Estadual de Campinas.

Silveira D, Raslan DS, Chiari E, Oliveira AB 1993. Trypanocidal effect of Lychnophora pinaster Mart. Mem I Oswaldo Cruz 88: 240.

Silveira D, Souza Filho JD, Oliveira AB, Raslan DS 2005. Lychnophoric acid from Lychnophora pinaster: a complete and unequivocal assignment by NMR spectroscopy. Ecl Quím 30: 37-41.

Zani CL, Chaves PPG, Queiroz R, Mendes NM, Oliveira AB, Cardoso JE, Anjos AMG, Grandi TS 1995. Brine shrimp lethality assay as a pre-screening system for anti-Trypanosoma cruzi. Phytomedicine 2: 47-50 